\title{
Effects of cyclopiazonic acid and dexamethasone on serotonin-induced calcium responses in vascular smooth muscle cells
}

\author{
Cigdem Selli • Metiner Tosun
}

Received: 20 October 2015 / Accepted: 20 January 2016 / Published online: 4 March 2016

(C) The Author(s) 2016. This article is published with open access at Springerlink.com

\begin{abstract}
We previously observed that sarcoendoplasmic reticulum $\mathrm{Ca}^{2+}$ ATPase (SERCA) blockade by cyclopiazonic acid (CPA) significantly potentiates serotonin (5-hydroxytryptamine (5-HT))-induced vascular contractions. Furthermore, 5-HT receptor antagonist methysergide partially inhibited CPApotentiated 5-HT contractions. In the present study, we further investigated whether SERCA inhibition potentiates 5-HT-induced $\mathrm{Ca}^{2+}$ responses along with attenuating the receptor antagonism by store-operated $\mathrm{Ca}^{2+}$ (SOC) entry and protein kinase $\mathrm{C}$ (PKC)-mediated mechanisms. The effects of dexamethasone that was previously shown to induce SOC entry and enhance 5HT responses were also tested. For this purpose, intracellular $\mathrm{Ca}^{2+}$ levels were monitored in A7r5 embryonic rat vascular smooth muscle cells by spectrofluorometry using the fluorescent indicator fura-2. The results showed that CPA, although not dexamethasone, significantly potentiated 5-HT-induced $\mathrm{Ca}^{2+}$ elevations. Ketanserin partially decreased 5-HT-induced and CPA-potentiated $\mathrm{Ca}^{2+}$ elevations whereas both PKC inhibitor D-sphingosine and SOC entry blocker 2aminoethoxydiphenyl borate (2-APB) abolished the
\end{abstract}

C. Selli $\cdot$ M. Tosun

Department of Pharmacology, Faculty of Pharmacy, Ege

University, 35040 Izmir, Turkey

C. Selli $(\bowtie)$

Applied Bioinformatics of Cancer, Edinburgh Cancer Research Centre, Institute of Genetics and Molecular Medicine,

Edinburgh EH4 2XU, UK

e-mail: cigdemselli@gmail.com remaining responses. The data suggests that diminished antagonistic effect on 5-HT-induced $\mathrm{Ca}^{2+}$ elevations in the presence of SERCA inhibition is induced by SOC entry and PKC activation.

Keywords CPA $\cdot$ Dexamethasone $\cdot \mathrm{PKC} \cdot$ Serotonin . SOC

\section{Introduction}

Serotonin (5-hydroxytryptamine (5-HT)) is found in the gastrointestinal tract, the central nervous system, and the bloodstream, primarily in platelets. 5-HT released from activated platelets regulates the function of vascular smooth muscle (VSM) cells through activating its $\mathrm{G}$ protein-coupled receptors (GPCRs), 5-HT $2 \mathrm{~A}$, and 5$\mathrm{HT}_{1 \mathrm{~B}} \cdot 5-\mathrm{HT}_{2 \mathrm{~A}}$ receptor activates phospholipase $\mathrm{C}$ (PLC) through Gq leading to the accumulation of inositol 1,4,5-trisphosphate $\left(\mathrm{IP}_{3}\right)$ that causes $\mathrm{Ca}^{2+}$ release from internal stores and di-acylglycerol (DAG) which activates protein kinase $\mathrm{C}$ (PKC) and voltage-operated $\mathrm{Ca}^{2+}$ channels [28]. 5-HT-elevated intracellular $\mathrm{Ca}^{2+}$ concentration $\left(\left[\mathrm{Ca}^{2+}\right]_{\mathrm{i}}\right)$ has been characterized by two steps, a transient phase due to $\mathrm{IP}_{3}$-induced $\mathrm{Ca}^{2+}$ release from internal stores and a plateau phase that mainly depends on the extracellular $\mathrm{Ca}^{2+}$ influx. $\mathrm{Ca}^{2+}$ release from cyclopiazonic acid (CPA)-sensitive intracellular stores and store-operated $\mathrm{Ca}^{2+}$ (SOC) entry also contribute to 5-HT-induced responses [25].

SOC entry is activated both by agonist-induced $\mathrm{Ca}^{2+}$ store depletion and by sarcoendoplasmic reticulum $\mathrm{Ca}^{2+}$ 
ATPase (SERCA) inhibitors such as thapsigargin and CPA. SERCA is essential to maintain $\left[\mathrm{Ca}^{2+}\right]_{\mathrm{i}}$ homeostasis through transporting cytosolic $\mathrm{Ca}^{2+}$ into stores besides regulating SOC entry [30]. In addition, SERCA dysfunction has been associated with many cardiovascular disorders including congestive heart failure, cardiac hypertrophy, pathological angiogenesis, as well as atherosclerosis [2]. Balloon injury-induced neointima formation in rat carotid arteries was prevented by SERCA2a gene transfer [23]. The initial report on the deficiency in cardiac SERCA levels in congestive heart failure due to myocardial infarction was published in 1996 [34]. The genetically targeted SERCA2a enzyme replacement therapy, Mydicar ${ }^{\circledR}$, is currently under clinical investigation for the treatment of advanced heart failure [13].

Switching from SERCA2a to SERCA2b isoform is the key difference between contractile and noncontractile (synthetic/proliferating) VSM phenotypes. It has been known for decades that VSM cells demonstrate phenotypic plasticity with a diverse range of phenotypes even at the differentiated state in contrast to most of other cell types. Although the plasticity is required for vascular development, switching from contractile to synthetic phenotype is also associated with vascular diseases [17]. The role of synthetic VSM cells in atherosclerosis whether they are the key pathogenic factor or beneficial by stabilizing the fibrous cap is still controversial [12]. Restoration of SERCA2a levels was shown to modify agonist-induced $\mathrm{Ca}^{2+}$ elevations and SOC entry as well as suppressing human VSM cell proliferation [7]. In accordance with these findings, we previously observed the upregulation of SERCA2b and SOC entry along with suppressed proliferation in $\mathrm{A} 7 \mathrm{r} 5$ cells during subculturing [9].

Corticosteroids also result in SERCA inhibition and disruption of $\mathrm{Ca}^{2+}$ homeostasis. It is well known that systemic corticosteroid application results in hypertension in normotensive patients and also worsening of blood pressure control in hypertensive patients mainly through increased renal salt and fluid retention. In addition to potentiating vasoconstrictor responses through increased receptor density [24, 26, 35], the actions of corticosteroids on calcium transport of VSM cells including SERCA levels and SOC entry were reported. Administration of triamcinolone, $80 \mathrm{mg} / \mathrm{kg}$ for 5 days, reduced SERCA mRNA levels in rat diaphragm suggesting a possible mechanism for fiber atrophy [10]. The synthetic corticosteroid dexamethasone has been shown to activate SOC entry via $\mathrm{Ca}^{2+}$-independent phospholipase $A_{2}$ in cultured myotubes, an in vitro model of muscle wasting [18].

SERCA downregulation also alters agonist-induced vascular responses and attenuates receptor antagonism. We previously showed that the inhibitory effects of endothelin-1 (ET-1) and 5-HT receptor antagonists on CPA-potentiated agonist-induced contractions significantly decreased in rat thoracic aorta $[32,33]$ suggesting the possible SERCA blockade-induced internalization $5 \mathrm{HT}_{2 \mathrm{~A}}$ receptors that are localized on caveolar membranes [5]. PKC has been shown to mediate 5-HTinduced $5-\mathrm{HT}_{2 \mathrm{~A}}$ internalization [6] via receptor phosphorylation which is followed by recycling back to the plasma membrane by protein phosphatase 2A (PP2A)mediated dephosphorylation [27].

Based on these data, we hypothesized that SOC entry and PKC activation are responsible for the decrease in 5HT receptor antagonism observed in the presence SERCA blockade. To test this hypothesis, we investigated the effects of SOC entry blocker 2-aminoethoxydiphenyl borate (2-APB) and PKC inhibitor (D-sphingosine) on CPApotentiated and 5-HT-induced $\mathrm{Ca}^{2+}$ responses in VSM cells. The abilities of dexamethasone to induce SOC entry and to potentiate 5-HT-induced $\mathrm{Ca}^{2+}$ responses in VSM cells were also tested.

\section{Materials and methods}

Cell culture

A7r5 cells derived from embryonic rat thoracic aorta (European Collection of Cell Cultures (ECACC)) fed with DMEM containing $10 \%$ fetal bovine serum and $2 \mathrm{mM}$ L-glutamine in flasks and maintained in a humidified incubator at $37{ }^{\circ} \mathrm{C}$ and $5 \% \mathrm{CO}_{2}$. When it reached $70 \%$ confluency, cells were subcultured (1:2) using $0.5 \%$ trypsin-EDTA. A detailed culturing protocol for A7r5 cells has been published recently [9].

Intracellular $\mathrm{Ca}^{2+}$ measurements

Intracellular $\mathrm{Ca}^{2+}$ levels were measured on cell populations (at passage numbers 22-24) using a dual wavelength spectrofluorometer (PTI QM8/2005, Photon Technology International, Birmingham, NJ) as described previously [31]. Briefly, A7r5 cells at passage numbers (P\#) 22-24 were seeded on round coverslips in 24-well plates at 20,000-30,000 cells/well density and 
then incubated for $24-48 \mathrm{~h}$ to reach a maximum of $70 \%$ confluency. In over confluent cells, spontaneous $\mathrm{Ca}^{2+}$ oscillations hindering the monitoring of agonist-induced responses were determined.

For the loading of $\mathrm{Ca}^{2+}$ indicator, cells were incubated in HEPES buffered saline (HBS; in millimolar; $\mathrm{NaCl} 135$, $\mathrm{KCl} 5.9, \mathrm{MgCl}_{2}$ 1.2, $\mathrm{CaCl}_{2}$ 1.5, HEPES 11.6, $\mathrm{NaHCO}_{3}$ 5.0 , glucose $11.5, \mathrm{pH} 7.3$ ) containing $5 \mu \mathrm{M}$ fura-2/AM plus $0.02 \%$ pluronic F-127 (Molecular Probes) supplemented with $1 \mathrm{mg} / \mathrm{ml} \mathrm{BSA}$ for $1 \mathrm{~h}$ at room temperature in the dark. After rinsing twice with HBS containing $1 \mathrm{mg} /$ $\mathrm{ml}$ BSA, cells on coverslips were mounted into a polymethacrylate spectrophotometer cuvette with the help of an apparatus. Fluorescence emission at $510 \mathrm{~nm}$ was monitored with excitation at 340 and $380 \mathrm{~nm}$ and expressed as ratio (340/380). Peak $\mathrm{Ca}^{2+}$ responses were evaluated due to time-dependent decays in plateau. Background fluorescence was determined by quenching the fura-2 fluorescence with $\mathrm{MnCl}_{2}(5 \mathrm{mM})$ in the presence of $10 \mu \mathrm{M}$ ionomycin in $\mathrm{Ca}^{2+}$-free solution containing $2 \mathrm{mM}$ EGTA at the end of the experiment.

\section{Chemicals}

All chemicals were from Sigma and dissolved in appropriate solvents as follows: 5-HT (PubChem CID: 164531) $\left(10^{-2} \mathrm{M}\right)$ in distilled water (DW); CPA (PubChem CID: 54695722) $\left(10^{-1} \mathrm{M}\right)$ in dimethylsulfoxide (DMSO); verapamil (PubChem CID: 155002) $\left(10^{-2} \mathrm{M}\right)$ in DW, methysergide (PubChem CID:5281073) $\left(10^{-2} \mathrm{M}\right)$ in DMSO; ketanserin $\left(10^{-1} \mathrm{M}\right)$ in EtOH; 2-APB (PubChem CID: 1598) $\left(10^{-1} \mathrm{M}\right)$ in DMSO; D-sphingosine (synthetic) (PubChem CID: 5280335) $\left(10^{-2} \mathrm{M}\right)$ in EtOH; and dexamethasone (PubChem CID: 5743) $\left(10^{-2} \mathrm{M}\right)$ in EtOH. In order to avoid direct vasorelaxant effects, final DMSO and EtOH concentrations did not exceed $0.1 \%$.

Data analysis

Data analyses as well as graphical presentations were prepared by using GraphPad Prism5. The results were given as mean \pm standard error of the mean. " $n$ " represents the number of samples used. The significance of differences was evaluated by Student's $t$ test for two groups and one-way ANOVA with post hoc Newman-Keuls test for multiple comparisons. $P<0.05$ was considered significant.

\section{Results}

5-HT-induced $\mathrm{Ca}^{2+}$ elevations

We previously showed that non-selective 5-HT receptor antagonist methysergide $(1 \mu \mathrm{M})$ abolished 5HT $(1 \mu \mathrm{M})$-induced contractions in rat thoracic aorta [32]. In the present study, we further investigated the nature and antagonism of 5-HT-induced $\mathrm{Ca}^{2+}$ elevations. The antagonistic effect of methysergide could not be tested due to the disruption of fura-2 fluorescence (data not shown). 5-HT was applied at $1 \mu \mathrm{M}$ final concentration that previously shown to induce measurable $\mathrm{Ca}^{2+}$ elevations in A7r5 cells $[9,31]$.

Administration of 5-HT resulted in two distinct $\mathrm{Ca}^{2+}$ responses: (i) a transient increase that significantly $(P<0.01, n=3)$ and completely (90\%) inhibited by ketanserin $(1 \mu \mathrm{M})$ and (ii) a steady elevation partially (32\%) reversed by ketanserin (Fig. 1). Figure 1 shows a continuous recording in which the second exposure to 5-HT elicits a steady response that is only weakly inhibited by cumulative doses of ketanserin. The remaining 5-HT steady responses were almost completely inhibited by voltage-operated $\mathrm{Ca}^{2+}$ channel blocker verapamil (1 $\mu \mathrm{M})$.

It is known that 5-HT leads to $\mathrm{Ca}^{2+}$ release from CPA-sensitive stores and SOC entry which constitute the first (transient) and second (plateau) phases of 5-HT responses, respectively. In light of this, we further investigated the effects of 2-APB on 5-HT steady elevations. A purported SOC entry blocker 2-APB [31] significantly $(P<0.01, n=4)$ but not completely inhibited the remaining $\mathrm{Ca}^{2+}$ elevations (Fig. 2a). Following the observation of the partial inhibition by 2 -APB $(50 \mu \mathrm{M})$, we further investigated the effects of D-sphingosine which is a potent and specific inhibitor of PKC. D-sphingosine $(10 \mu \mathrm{M})$ abolished $(P<0.01, n=4)$ the remaining responses following 2-APB inhibition (Fig. 2a). The effect of D-sphingosine on ketanserininhibited responses was further investigated in the absence of 2-APB (Fig. 2b). Although 5-HTinduced steady $\mathrm{Ca}^{2+}$ elevations were significantly $(P<0.05)$ higher in Fig. 2a compared to Fig. 2b, this discrepancy was inevitable in experimental conditions. D-sphingosine $(10 \mu \mathrm{M})$ abolished $(P<0.01, n=4)$ the responses when applied following ketanserin (Fig. 2b) as well. 

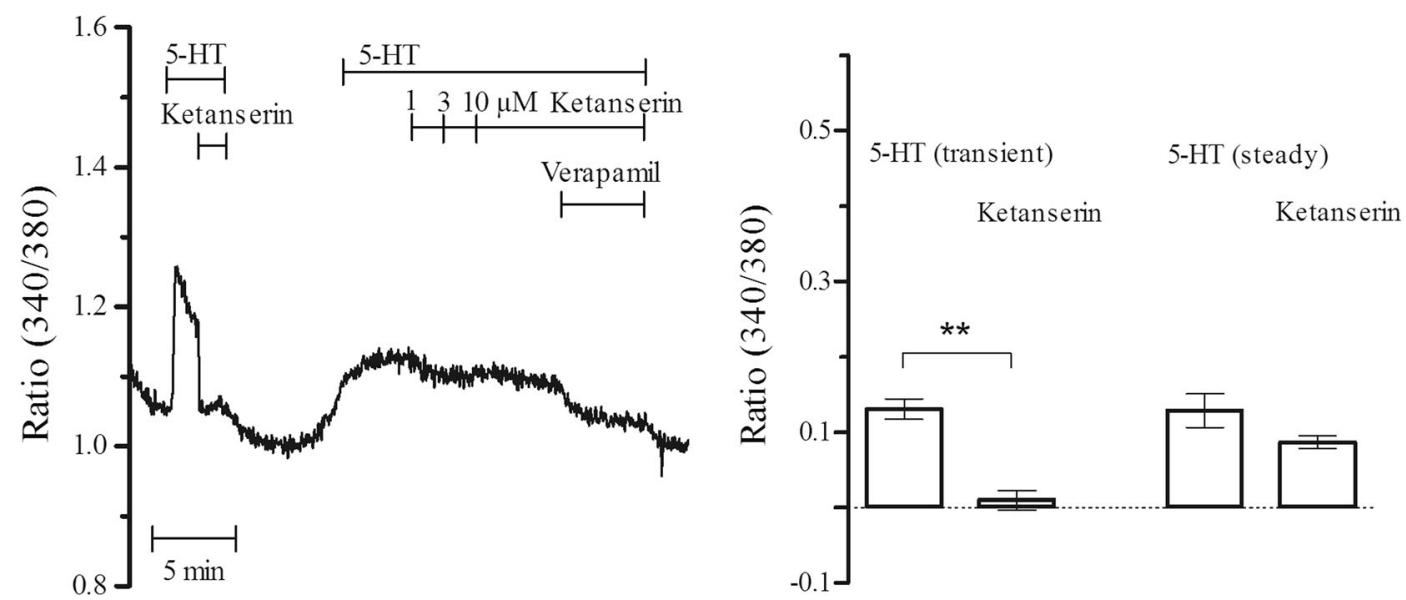

Fig. 1 5-HT-induced $\mathrm{Ca}^{2+}$ elevations. Transient and steady elevations of $\mathrm{Ca}^{2+}$ in response to 5-HT $(1 \mu \mathrm{M})$ and the effects of ketanserin $(1 \mu \mathrm{M})$ and verapamil $(1 \mu \mathrm{M})$ on 5 -HT-induced elevations $(* * P<0.01, n=3)$

Effects of CPA on 5-HT-induced $\mathrm{Ca}^{2+}$ elevations

$\mathrm{CPA}$, at $10 \mu \mathrm{M}$ concentration that depletes SR-stored $\mathrm{Ca}^{2+}$, potentiated 5-HT contractile responses and attenuated 5-HT receptor antagonism in endotheliumdenuded rat thoracic aorta [32]. The effects of CPA on 5-HT-induced $\mathrm{Ca}^{2+}$ elevations further investigated in the present study. CPA significantly potentiated 5-HT $(1 \mu \mathrm{M})$-induced $\mathrm{Ca}^{2+}$ responses which were partially inhibited $(P<0.05, n=4)$ by $1 \mu \mathrm{M}$ ketanserin (Fig. 3 ). Furthermore, both 2-APB $(50 \mu \mathrm{M})$ and D-sphingosine (at $10 \mu \mathrm{M}$ that reportedly inhibits 5-HT receptor internalization [6]) significantly $(P<0.01, n=4)$ reversed the remaining responses (Fig. 3).

Effects of dexamethasone on 5-HT-induced $\mathrm{Ca}^{2+}$ elevations

In addition to CPA, the effects of dexamethasone that reportedly activates SOC entry in cultured myotubes [18] were tested. An insignificant increase in 5-HT $(1 \mu \mathrm{M})$-induced $\mathrm{Ca}^{2+}$ responses was observed with the addition of dexamethasone $(10 \mu \mathrm{M})$ which was partially inhibited by $1 \mu \mathrm{M}$ ketanserin and $50 \mu \mathrm{M} 2$-APB (Fig. 4). D-sphingosine $(10 \mu \mathrm{M})$ abolished $(P<0.01$, $n=4$ ) the rest of 5-HT responses (Fig. 4).

\section{Discussion}

We previously showed that $5 \mathrm{HT}_{2 \mathrm{~A}}$ receptor antagonist methysergide completely inhibited 5-HT-induced vascular contractions in rat thoracic aorta [32]. However, monitoring the inhibitory effects of methysergide on 5-HT-induced $\mathrm{Ca}^{2+}$ elevations in A7r5 cells was not possible due to its spectral properties interfering fura-2 signal. Therefore, another $5-\mathrm{HT}_{2 \mathrm{~A}}$ receptor antagonist ketanserin with potent inhibitory effects on vasoconstrictor action of 5-HT was used. We observed two distinct responses to 5-HT, transient and steady. 5-HT steady responses were served as control for further experiments investigating the effects of CPA and dexamethasone.

Transient and steady $\mathrm{Ca}^{2+}$ responses to 5-HT

During VSM phenotypic alteration, $\mathrm{Ca}^{2+}$ handling switches from voltage-sensitive to SOC and receptoroperated $\mathrm{Ca}^{2+}$ entries and also $\mathrm{Ca}^{2+}$ transients are replaced with steady-state $\mathrm{Ca}^{2+}$ elevations [4]. The mode of intracellular $\mathrm{Ca}^{2+}$ elevations also determines the type of VSM contraction. Oscillatory type of $\mathrm{Ca}^{2+}$ transient triggers phasic contractions whereas a steady-state increase in $\mathrm{Ca}^{2+}$ triggers tonic contractions which had been observed in synthetic phenotype [1]. Ketanserinsensitive and transient $\mathrm{Ca}^{2+}$ elevations to 5-HT were previously reported in primary cultured smooth muscle cells [20]. We observed both transient and profoundly steady $\mathrm{Ca}^{2+}$ elevations in VSM cell line. Steady 5-HT responses were partially sensitive to ketanserin in contrast to transient elevations which were completely inhibited by ketanserin. 5-HT-induced steady $\mathrm{Ca}^{2+}$ elevations observed in our study may be responsible for tonic vasoconstriction supporting its role in pulmonary 

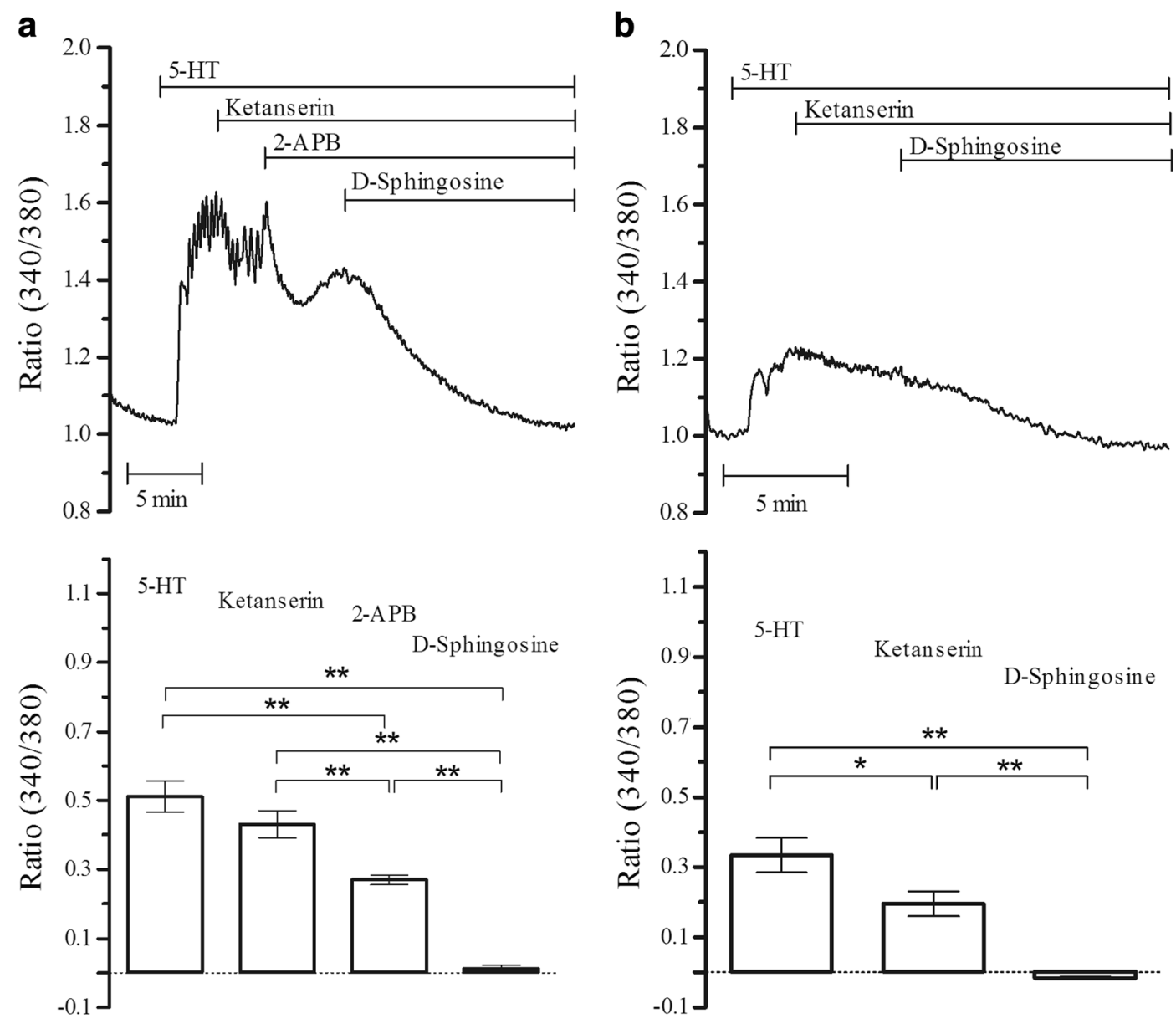

Fig. 2 Inhibition of 5-HT-induced $\mathrm{Ca}^{2+}$ elevations. a 2-APB $(50 \mu \mathrm{M})$ and D-sphingosine $(10 \mu \mathrm{M})$ were sequentially applied on ketanserin $(1 \mu \mathrm{M})$-inhibited 5-HT $(1 \mu \mathrm{M})$ responses

hypertension [8], and steady elevations may also account for the partial reduction of pulmonary vascular resistance by ketanserin [15]. In cultured rat aortic smooth muscle cells, dose-dependent increases in 5HT-induced intracellular $\mathrm{Ca}^{2+}$ elevations were inhibited by ketanserin [16]. However, in another study performed with the same cell type ketanserin, along with cinanserin and mianserin, it was found to be less effective on 5-HT-induced $\mathrm{Ca}^{2+}$ elevations in comparison to sarpogrelate [29]. The discrepancies in 5-HT responses and 5-HT receptor antagonism even in the same cell population may result from spatiotemporal changes in $\mathrm{Ca}^{2+}$ signaling and related protein localization. Since restoring SERCA2a levels in synthetic VSM cells modifies the type of 5-HT-induced $\mathrm{Ca}^{2+}$ transients from steady-state to transient mode [7], differential

localization of SERCA2a may be responsible for two distinct 5-HT responses observed in our study. We also previously reported that culturing conditions and passaging alter the expression of $\mathrm{Ca}^{2+}$-related proteins in A $7 r 5$ cells that mimic the phenotypic switching of VSM cells [9]. The discrepancies in ketanserin responses observed in different studies may result from different passage numbers and cell culturing conditions. The observation of both ketanserin-sensitive and ketanserin-insensitive 5-HT responses in the present study may also support the utility of A7r5 in the investigation of VSM cell differentiation.

In addition, the steady 5-HT responses were partially (30\%) reversed by ketanserin whereas completely inhibited both by 2-APB and D-sphingosine suggesting the contribution of SOC entry and PKC activation in 

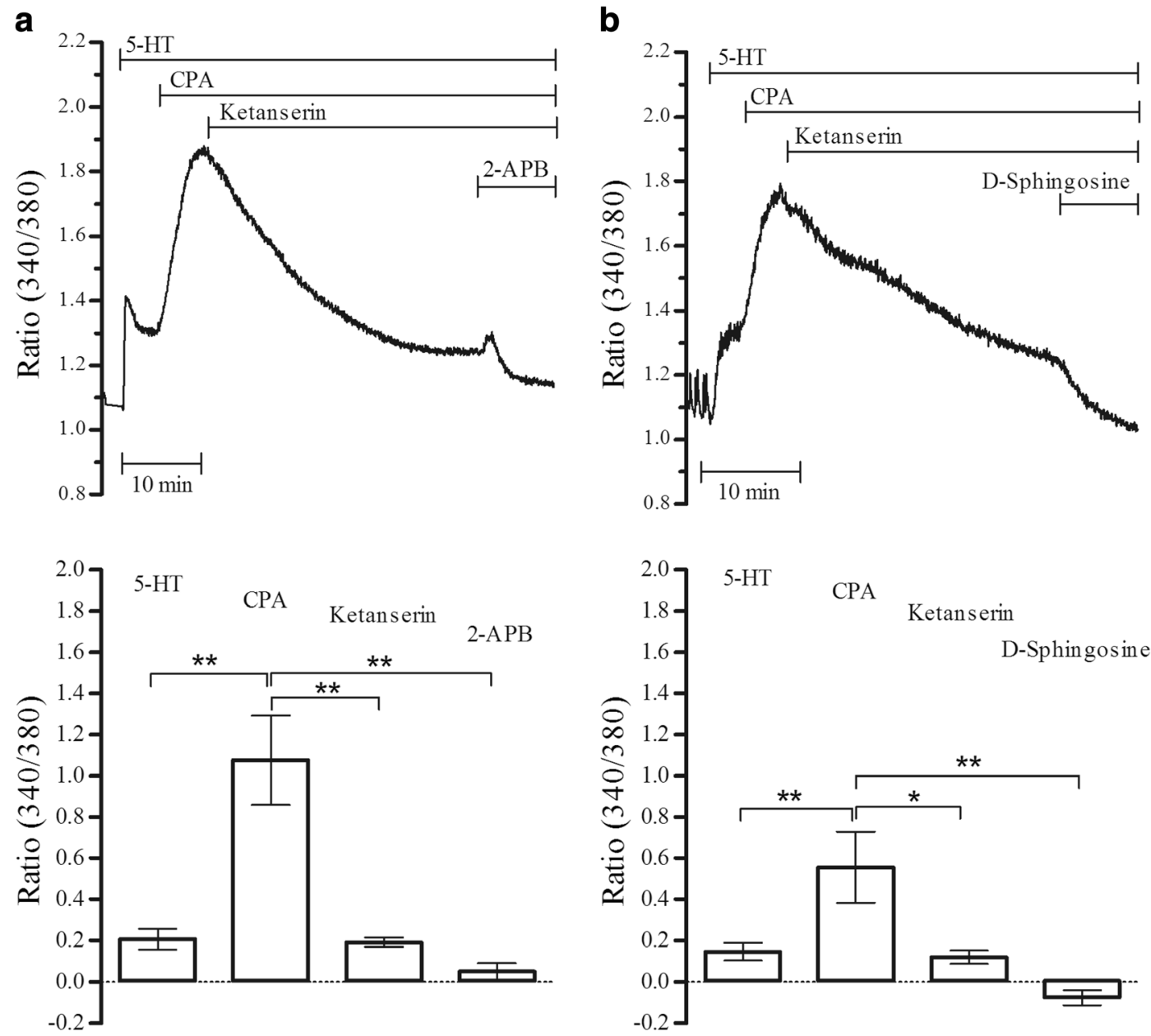

Fig. 3 Inhibition of CPA-potentiated 5-HT-induced $\mathrm{Ca}^{2+}$ elevations. a The effects of ketanserin $(1 \mu \mathrm{M})$ and 2-APB $(50 \mu \mathrm{M})$ on CPA $(10 \mu \mathrm{M})$-potentiated 5 -HT $(1 \mu \mathrm{M})$ responses $(* * P<0.01$,

$n=4)$. b Ketanserin $(1 \mu \mathrm{M})$ and D-sphingosine $(10 \mu \mathrm{M})$ were sequentially applied on 5-HT-induced and CPA $(10 \mu \mathrm{M})$-potentiated elevations $(* P<0.05, * * P<0.01, n=4)$
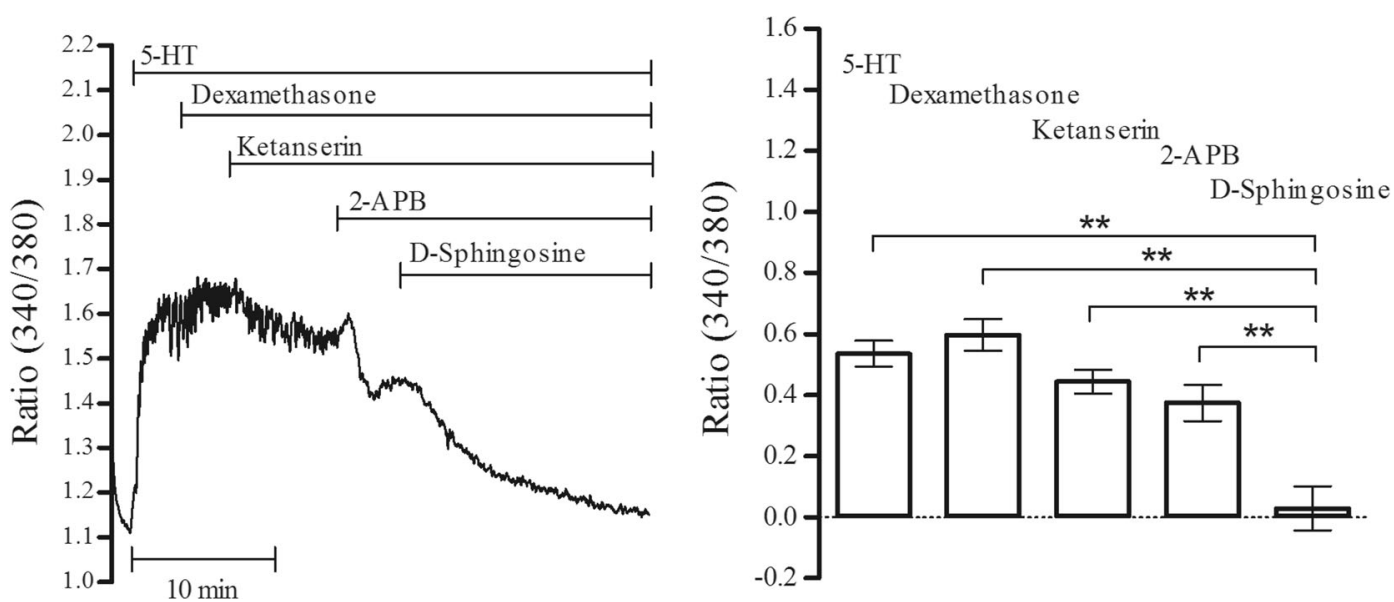

Fig. 4 Effects of dexamethasone on 5-HT-induced $\mathrm{Ca}^{2+}$ elevations. Dexamethasone $(10 \mu \mathrm{M})$, ketanserin $(1 \mu \mathrm{M}), 2-\mathrm{APB}(50 \mu \mathrm{M})$, and Dsphingosine $(10 \mu \mathrm{M})$ were sequentially applied on 5 -HT $(1 \mu \mathrm{M})$-induced $\mathrm{Ca}^{2+}$ responses $(* * P<0.01, n=3)$ 
altered 5-HT-induced $\mathrm{Ca}^{2+}$ mobilization. 5-HT-induced steady $\mathrm{Ca}^{2+}$ response may result in PKC-mediated phosphorylation and sequential internalization of receptor resulting in decreased antagonistic effect.

\section{SERCA inhibition potentiates 5-HT-induced $\mathrm{Ca}^{2+}$ responses}

Enhancement of contractile responses to 5-HT is related to cardiovascular diseases, such as atherosclerosis. Endothelial dysfunction is characterized by reduced endothelium-dependent relaxations and an early marker of atherosclerosis, a chronic inflammatory disease affecting the peripheral arteries and the aorta. Endothelial dysfunction also contributes to increased vasoconstriction induced by endothelium-dependent agonists such as 5-HT. Contractile responses to 5-HT, a major product of platelet activation, were potentiated in coronary arteries of atherosclerotic monkeys and reversed to normal by reducing dietary cholesterol [21]. Furthermore, 5-HT has constricting effects contributing to myocardial ischemia and coronary artery disease in contrast to its vasodilating effect on normal human coronary arteries [11]. It is also known that acute hypertension potentiates 5-HT constrictor responses in coronary arteries by impairing endothelial function [22] along with the enhancement of 5-HTstimulated $\left[\mathrm{Ca}^{2+}\right]_{\mathrm{i}}$-dependent thoracic and abdominal aortic contractions in chronic hypertension [3].

We observed that CPA-mediated SERCA inhibition that mimics impaired SERCA activity which is also a characteristic of synthetic VSM cells [23] potentiated 5HT-induced $\mathrm{Ca}^{2+}$ elevations. When applied alone, CPA $(10 \mu \mathrm{M})$ causes contraction of endothelium-denuded rat thoracic aorta as well as elevating $\left[\mathrm{Ca}^{2+}\right]_{\mathrm{i}}$ in VSM cells [31]. In addition to its PKC-mediated contractile effects, CPA was shown to augment 5-HT- and ET-1-induced vasoconstrictions and to diminish inhibitory actions of their receptor blockers $[32,33]$. In accordance with our previous findings in rat aortic rings, SERCA inhibition potentiated 5-HT-induced $\mathrm{Ca}^{2+}$ elevations in VSM cells. In contrast to enhanced 5-HT responses observed in our study, SERCA blockers thapsigargin and cyclopiazonic acid were previously shown to inhibit 5-HT-induced $\mathrm{Ca}^{2+}$ elevations in rat aortic smooth muscle cells [29].

Since we previously reported that verapamil had no effect on CPA-induced $\mathrm{Ca}^{2+}$ elevations [31], the CPA response appears to be related to SOC entry without the contribution of voltage-operated $\mathrm{Ca}^{2+}$ channels. Ketanserin partially decreased CPA-potentiated 5-HT- induced $\mathrm{Ca}^{2+}$ elevations whereas both PKC inhibitor Dsphingosine and SOC blocker 2-APB abolished the remaining of ketanserin-inhibited responses. This suggests that SERCA blockade-induced SOC entry contributes to the increased $\mathrm{Ca}^{2+}$ levels and activation of PKC. It was reported that $\mathrm{PKC}$-mediated pathway rather than the release of stored $\mathrm{Ca}^{2+}$ plays a primary role in 5-HTand histamine-induced coronary spasm [19]. PKC was also suggested to have a role in the recycling of $5-\mathrm{HT}_{2 \mathrm{~A}}$ receptors [6]. These results support that the decrease in 5-HT receptor antagonism in the presence of CPA may result from PKC-mediated internalization of 5- $\mathrm{HT}_{2 \mathrm{~A}}$ receptors which have been shown to localize on caveolar membranes [5]. Since sphingosine reportedly counteracts PKC's effects by regulating PP2A [14], it may facilitate the translocation of internalized $5-\mathrm{HT}_{2 \mathrm{~A}}$ receptors back to the cellular membrane making them available for antagonistic intervention. However, further investigation is required to confirm 5-HT receptor localization using imaging techniques such as total internal reflection fluorescence (TIRF) that are well suited for visualizing single molecules.

\section{Dexamethasone and 5-HT-induced $\mathrm{Ca}^{2+}$ elevations}

Enhanced vascular sensitivity to 5-HT through increased mobilization of $\mathrm{Ca}^{2+}$ from cellular stores was observed in femoral arteries of deoxycorticosterone acetate (DOCA)salt hypertensive rats [24]. In another study performed with C6 glioma cells, dexamethasone was shown to potentiate 5-HT-induced responses with a ninefold leftward shift in 5-HT dose-response curves [26]. Furthermore, ketanserin completely inhibited 5-HT-induced time- and dose-dependent increases in $\left[\mathrm{Ca}^{2+}\right]_{\mathrm{i}}$ as well as those potentiated by dexamethasone [26]. Dexamethasone was shown to induce the rapid promotion of norepinephrine-mediated rat VSM cell contraction as well [35]. In addition, dexamethasone activates SOC entry and protein degradation in myotubes suggesting the possible involvement of SOC entry in glucocorticoid-induced muscle protein degradation [18].

In contrast to these findings, dexamethasone induced a slight increase in 5-HT-induced $\mathrm{Ca}^{2+}$ elevations in our study. In the presence of dexamethasone, the attenuation of the antagonistic effect of ketanserin on 5-HT-induced $\mathrm{Ca}^{2+}$ elevations was similar to control responses (26 and $16 \%$, respectively). However, 5-HT responses in the presence of dexamethasone were not significantly inhibited by $2-\mathrm{APB}$ in contrast to the control (37 and 
$47 \%$, respectively) suggesting the contribution of SOC entry-independent mechanisms to dexamethasoneinduced $\mathrm{Ca}^{2+}$ elevations in $\mathrm{A} 7 \mathrm{r} 5$ cells. The results may help to clarify the differential effects of CPA and dexamethasone, both agents activate SOC entry with different mechanisms and efficiencies, on 5-HT-evoked responses.

In conclusion, our findings suggest that decreased 5HT receptor antagonism in the presence of SERCA inhibition is mediated by SOC entry and PKC activation. Furthermore, 5-HT-induced steady $\mathrm{Ca}^{2+}$ elevations may facilitate tonic vasoconstriction associated with vasospastic diseases. Our results may contribute to the elucidation of the underlying mechanisms and the treatment of vascular diseases related to SERCA downregulation and 5HT hyperreactivity. The attenuated 5-HT receptor antagonism in the presence of SERCA inhibition observed in our study may mimic the phenotypic switching of VSM cells and alter $\mathrm{Ca}^{2+}$ signaling in some vascular diseases [17]. However, the major limitation of our study is the lack of physiopathological context. Therefore, the functional role of the attenuation of 5-HT receptor antagonism and SERCA downregulation needs further investigation using cardiovascular disease models.

Acknowledgments This work was supported by the Ege University Research Project [BAP-14ECZ022] to Cigdem Selli.

Open Access This article is distributed under the terms of the Creative Commons Attribution 4.0 International License (http:// creativecommons.org/licenses/by/4.0/), which permits unrestricted use, distribution, and reproduction in any medium, provided you give appropriate credit to the original author(s) and the source, provide a link to the Creative Commons license, and indicate if changes were made.

\section{References}

1. Aalkjaer C, Nilsson H (2005) Vasomotion: cellular background for the oscillator and for the synchronization of smooth muscle cells. Br J Pharmacol 144(5):605-616

2. Adachi T (2010) Modulation of vascular sarco/endoplasmic reticulum calcium ATPase in cardiovascular pathophysiology. Adv Pharmacol 59:165-195

3. Bell DR (1995) Effect of chronic high-pressure on transient and tonic vascular contractions to serotonin in hypertension. Am J Hypertens 8(4):365-374

4. Berra-Romani R, Mazzocco-Spezzia A, Pulina MV, Golovina VA (2008) Ca2+ handling is altered when arterial myocytes progress from a contractile to a proliferative phenotype in culture. Am J Physiol Cell Physiol 295(3):C779-C790

5. Bhatnagar A, Sheffler DJ, Kroeze WK, Compton-Toth B, Roth BL (2004) Caveolin-1 interacts with 5-HT2A serotonin receptors and profoundly modulates the signaling of selected
Galphaq-coupled protein receptors. J Biol Chem 279(33): 34614-34623

6. Bhattacharyya S, Puri S, Miledi R, Panicker MM (2002) Internalization and recycling of 5-HT2A receptors activated by serotonin and protein kinase $\mathrm{C}$-mediated mechanisms. Proc Natl Acad Sci U S A 99(22):14470-14475

7. Bobe R, Hadri L, Lopez JJ, Sassi Y, Atassi F, Karakikes I, Liang L, Limon I, Lompre AM, Hatem SN, Hajjar RJ, Lipskaia L (2011) SERCA2a controls the mode of agonistinduced intracellular $\mathrm{Ca} 2+$ signal, transcription factor NFAT and proliferation in human vascular smooth muscle cells. J Mol Cell Cardiol 50(4):621-633

8. Egermayer P, Town GI, Peacock AJ (1999) Role of serotonin in the pathogenesis of acute and chronic pulmonary hypertension. Thorax 54(2):161-168

9. Erac Y, Selli C, Filik P, Tosun M (2014) Effects of passage number on proliferation and store-operated calcium entry in A7r5 vascular smooth muscle cells. J Pharmacol Toxicol Methods 70(1):1-5

10. Gayan-Ramirez G, Vanzeir L, Wuytack F, Decramer M (2000) Corticosteroids decrease mRNA levels of SERCA pumps, whereas they increase sarcolipin mRNA in the rat diaphragm. J Physiol Lond 524(2):387-397

11. Golino P, Piscione F, Willerson JT, Cappellibigazzi M, Focaccio A, Villari B, Indolfi C, Russolillo E, Condorelli M, Chiariello M (1991) Divergent effects of serotonin on coronary-artery dimensions and blood-flow in patients with coronary atherosclerosis and control patients. N Engl J Med 324(10):641-648

12. Gomez D, Owens GK (2012) Smooth muscle cell phenotypic switching in atherosclerosis. Cardiovasc Res 95(2):156-164

13. Greenberg B, Yaroshinsky A, Zsebo KM, Butler J, Felker GM, Voors AA, Rudy JJ, Wagner K, Hajjar RJ (2014) Design of a phase $2 b$ trial of intracoronary administration of AAV1/SERCA2a in patients with advanced heart failure: the CUPID 2 trial (calcium up-regulation by percutaneous administration of gene therapy in cardiac disease phase $2 b$ ). JACC Heart Fail 2(1):84-92

14. Habrukowich C, Han DK, Le A, Rezaul K, Pan W, Ghosh M, Li ZG, Dodge-Kafka K, Jiang XJ, Bittman R, Hla T (2010) Sphingosine interaction with acidic leucine-rich nuclear phosphoprotein-32A (ANP32A) regulates PP2A activity and cyclooxygenase (COX)-2 expression in human endothelial cells. J Biol Chem 285(35):26825-26831

15. Hamet A, Kral B, Cernohorsky D (1985) Comparative effects of oxygen, nifedipine and ketanserin in hypoxic pulmonary hypertension. Cor Vasa 27(6):406-411

16. Hirafuji M, Nezu A, Kanai Y, Ebihara T, Kawahara F, Tanimura A, Minami M (1998) Effect of 5hydroxytryptamine on intracellular calcium dynamics in cultured rat vascular smooth muscle. Res Commun Mol Pathol Pharmacol 99(3):305-319

17. House SJ, Potier M, Bisaillon J, Singer HA, Trebak M (2008) The non-excitable smooth muscle: calcium signaling and phenotypic switching during vascular disease. Pflugers Arch 456(5):769-785

18. Itagaki K, Menconi M, Antoniu B, Zhang Q, Gonnella P, Soybel D, Hauser C, Hasselgren PO (2010) Dexamethasone stimulates store-operated calcium entry and protein degradation in cultured L6 myotubes through a phospholipase A(2)- 
dependent mechanism. Am J Physiol Cell Physiol 298(5): C1127-C1139

19. Kadokami T, Shimokawa H, Fukumoto Y, Ito A, Takayanagi T, Egashira K, Takeshita A (1996) Coronary artery spasm does not depend on the intracellular calcium store but is substantially mediated by the protein kinase $\mathrm{C}$-mediated pathway in a swine model with interleukin-1 beta in vivo. Circulation 94(2):190-196

20. Kanaide H, Hasegawa M, Kobayashi S, Nakamura M (1987) Serotonin-induced cytosolic free calcium transients in cultured vascular smooth-muscle cells. Biochem Biophys Res Commun 143(2):532-538

21. Lamping KG, Piegors DJ, Benzuly KH, Armstrong ML, Heistad DD (1994) Enhanced coronary vasoconstrictive response to serotonin subsides after removal of dietarycholesterol in atherosclerotic monkeys. Arterioscler Thromb 14(6):951-957

22. Lamping KG, Dole WP (1987) Acute hypertension selectively potentiates constrictor responses of large coronary arteries to serotonin by altering endothelial function in vivo. Circ Res 61(6):904-913

23. Lipskaia L, del Monte F, Capiod T, Yacoubi S, Hadri L, Hours M, Hajjar RJ, Lompre AM (2005) Sarco/endoplasmic reticulum $\mathrm{Ca} 2+$-ATPase gene transfer reduces vascular smooth muscle cell proliferation and neointima formation in the rat. Circ Res 97(5):488-495

24. Mecca TE, Webb RC (1984) Vascular-responses to serotonin in steroid hypertensive rats. Hypertension 6(6):887-892

25. Moneer Z, Pino I, Taylor EJ, Broad LM, Liu Y, Tovey SC, Staali L, Taylor CW (2005) Different phospholipase-Ccoupled receptors differentially regulate capacitative and non-capacitative Ca2+ entry in A7r5 cells. Biochem J 389(Pt 3):821-829

26. Muraoka SI, Mikuni M, Kagaya A, Saitoh K, Takahashi K (1993) Dexamethasone potentiates serotonin-2 receptor-mediated intracellular $\mathrm{Ca} 2+$ mobilization in $\mathrm{C} 6$ glioma cells. Neuroendocrinology 57(2):322-329
27. Raote I, Bhattacharyya S, Panicker MM (2013) Functional selectivity in serotonin receptor 2A (5-HT2A) endocytosis, recycling, and phosphorylation. Mol Pharmacol 83(1):42-50

28. Rodat-Despoix L, Aires V, Ducret T, Marthan R, Savineau JP, Rousseau E, Guibert C (2009) Signalling pathways involved in the contractile response to 5-HT in the human pulmonary artery. Eur Respir J 34(6):1338-1347

29. Saini HK, Sharma SK, Zahradka P, Kumamoto H, Takeda N, Dhalla NS (2003) Attenuation of the serotonin-induced increase in intracellular calcium in rat aortic smooth muscle cells by sarpogrelate. Can J Physiol Pharmacol 81(11):1056-1063

30. Satoh K, Matsu-Ura T, Enomoto M, Nakamura H, Michikawa T, Mikoshiba K (2011) Highly cooperative dependence of sarco/endoplasmic reticulum calcium ATPase (SERCA) 2a pump activity on cytosolic calcium in living cells. J Biol Chem 286(23):20591-20599

31. Selli C, Erac Y, Kosova B, Tosun M (2009) Posttranscriptional silencing of TRPC1 ion channel gene by RNA interference upregulates TRPC6 expression and storeoperated $\mathrm{Ca} 2+$ entry in $\mathrm{A} 7 \mathrm{r} 5$ vascular smooth muscle cells. Vasc Pharmacol 51(2-3):96-100

32. Selli C, Erac Y, Tosun M (2014) Cyclopiazonic acid alters serotonin-induced responses in rat thoracic aorta. Vasc Pharmacol 61(2-3):43-48

33. Tosun M, Erac Y, Selli C, Karakaya N (2006) Sarcoplasmicendoplasmic reticulum $\mathrm{Ca} 2+-\mathrm{ATPa} e$ inhibition prevents endothelin A receptor antagonism in rat aorta. Am J Physiol Heart Circ Physiol 292:H1961-H1966

34. Zarain-Herzberg A, Afzal N, Elimban V, Dhalla NS (1996) Decreased expression of cardiac sarcoplasmic reticulum $\mathrm{Ca}(2+)$-pump ATPase in congestive heart failure due to myocardial infarction. Mol Cell Biochem 163-164:285-290

35. Zhang T, Shi WL, Tasker JG, Zhou JR, Peng YL, Miao CY, Yang YJ, Jiang CL (2013) Dexamethasone induces rapid promotion of norepinephrine-mediated vascular smooth muscle cell contraction. Mol Med Rep 7(2):549-554 